\title{
Chemical and viability changes during fermentation and cold storage of fermented milk manufactured using yogurt and probiotic bacteria.
}

\author{
Damin, M.R. ${ }^{1}$, Minowa, E. ${ }^{1}$, Alcântara, M.R. ${ }^{2}$, Oliveira, M.N. ${ }^{1 *}$ \\ ${ }^{1}$ Faculty of Pharmaceutical Sciences, São Paulo University, Av Prof Lineu Prestes, 580. B1 \\ 16, 05508-900, São Paulo, Brazil. \\ ${ }^{2}$ University of São Paulo, Chemistry Institute, Av Professor Lineu Prestes, 580 Bloco 3, \\ 05508-900 São Paulo, Brazil
}

\begin{abstract}
The objective of the present work was to study probiotic fermented milks during fermentation process and cold storage. Two strains of probiotic bacteria were used: Lactobacillus acidophilus (LA) and Bifidobacterium animalis subsp. lactis (BL). The yogurt culture Lactobacillus bulgaricus (LB) was used as control. All strains were employed in coculture with the starter Streptococcus thermophilus (ST). Commercial skimmed milk powder

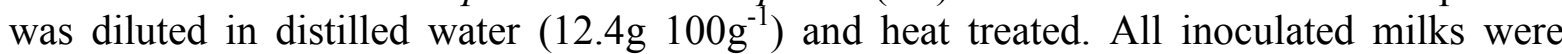
incubated for fermentation at $42^{\circ} \mathrm{C}$ in a water bath until $\mathrm{pH} 4.50$ was reached. Chemical changes during fermentation were followed by measuring: $V_{m}$ (maximum acidification rate that measures the decrease of $\mathrm{pH}$ units per minute and the values are expressed as $\mathrm{mUpH} / \mathrm{min}$ ), $\mathrm{t}_{\mathrm{Vmax}}$ (time to achieve the maximum acidification rate, in $\mathrm{h}$ ), $\mathrm{t}_{\mathrm{pH} 5,0}$ (time to achieve $\mathrm{pH} 5.0$, in $\mathrm{h}$ ) and $\mathrm{t}_{\mathrm{pH} 4.5}$ (time necessary to reach $\mathrm{pH} 4.5$, in $\mathrm{h}$ ). Rheological behavior was determined at $\mathrm{d} 1$ and firmness, $\mathrm{pH}$ and viability were followed until 28 days of storage at $4^{\circ} \mathrm{C}$. Fermentation time for probiotic cultures was longer than for yogurt culture. $\mathrm{pH}$ decreased and firmness increased during storage. The main change occurred in the first week. Probiotic bacteria grow during fermentation. ST dominated over the other strains and remained stable during all storage period. B. lactis and L. bulgaricus attain the final storage period stable. L. acidophilus, however, decreased before 14 days of storage and at d 28 doesn't fit the minimum requirements to achieve beneficial properties to health.
\end{abstract}

Key-words: probiotic, kinetics, viability and texture

* Corresponding author: tel: +55 1130913690

E-mail address: monolive@usp.br

\section{INTRODUCTION}

Major developments in functional foods area include the selection and use of beneficial probiotic microorganisms. They are defined as "microbial cells preparations or components of microbial cells that have a beneficial effect on health and well being of the host" (Gardiner et al., 2002). Although the probiotic market development includes many dairy foods, fermented foods remain the main vehicle of administration of probiotic and yogurt is far the most important in this group (Tamime et al., 1995; Lourens-Hatting and Viljoen, 2001). Health related benefits associated with the consumption of probiotic micro-organisms could be summarized as: enhancement of immune modulation and prevention of certain diseases and/or ailments in humans (Goldin, 1998; Holzapfel et al., 1998; Salminen et al., 1998; Mattila-Sandholm et al., 1999; Ouwehand et al., 2003). 
In order to produce the desired benefits, probiotic bacteria should be present in the product in high viable counts at the moment of consumption. Kurmann and Rasic (1991) recommended that the minimum therapeutic daily dose is $10^{8}-10^{9}$ colony forming units $(\mathrm{cfu}) / \mathrm{mL}$. Although this level is not well established, it should vary according to the species and the strain which is used. Other researchers have suggest a level higher than $10^{7}-10^{8} \mathrm{cfu} / \mathrm{mL}$ (Rybka and Kailasapathy, 1995; Dave and Shah, 1997; Kailasapathy and Rybka, 1997); however, this could be achieved through a daily intake of $100 \mathrm{~mL}$ of dairy products containing $10^{7} \mathrm{cfu} / \mathrm{mL}$ of probiotic bacteria (Oliveira et al., 2002). These probiotic micro-organisms often show poor viability in commercial preparations, and several factors have been identified in fermented milk that can affect their viability, such as the $\mathrm{pH}$ and acidity levels, presence of other micro-organisms, temperature of incubation and/or the presence of oxygen (Shah et al., 1995; Kailasapathy and Ribka, 1997; Shah, 2000). Probiotic cultures with good technological performance should improve quick acidification in milk, provide adequate sensory properties to the product, and be viable during the storage period (Oliveira et al., 2001). Under commercial practice, it is very common to use yogurt starter culture (i.e. Streptococcus thermophilus and Lactobacillus delbrueckii subsp. bulgaricus) in combination with the probiotic bacteria in order to reduce the fermentation time. L. delbrueckii subsp. bulgaricus tend to post-acidify the fermented milk, which affects the viability of the probiotic bacteria; thus, it is recommended to use starter cultures devoid of L. delbrueckii subsp. bulgaricus (Dave and Shah, 1998).

One of the most important attributes for yogurt is texture, which is affected mainly by the milk base heating, starter culture and yogurt shearing after fermentation. Lucey et al. (1998) found that high heat treatment cause high protein denaturation $(>50 \%)$, associated with a marked increase in complex viscosity. Penetrometry or dynamic tests give information on the viscoelastic behavior of yogurt. Penetrometers are used to perform the puncture test, which measures the force required to push a probe into yogurt at a fixed depth of penetration. This force is called hardness or firmness. Rheometers working in dynamic mode permit the calculation of storage modulus and loss modulus, describing the elastic and viscous properties of the gelling system. Complex viscosity is other descriptor often used. In linear viscoelastic region the structure is kept and gel properties can be characterized (Sodini et al., 2004).

The objective of the present work was to study the chemical and viability changes during fermentation and cold storage of fermented milk manufactured using yogurt and probiotic bacteria.

\section{MATERIAL AND METHODS}

\section{Microbial cultures}

Four commercial cultures (Danisco, France) were used: Streptococcus thermophilus, TA040 (ST) plus one strain each of Lactobacillus delbrueckii ssp. bulgaricus (yoghurt cultures), LB340 (LB), and Lactobacillus acidophilus, LAC4 (LA) and Bifidobacterium animalis subsp. lactis (BL) (probiotic cultures). Pure strain spray-dried inocula were diluted individually in $50 \mathrm{~mL}$ of sterilized milk $40 \mathrm{~min}$ before use. Initial counts were $\sim 10^{7} \mathrm{cfu} / \mathrm{mL}$. 


\section{Fermented milk manufacture}

Commercial skimmed milk powder (Molico, Nestlé, Brazil) was diluted in distilled water to

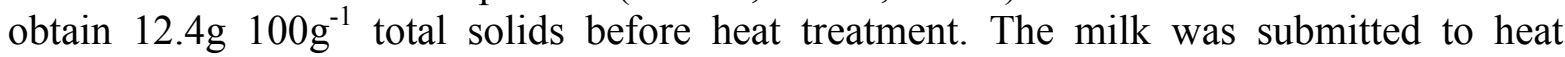
treatment in water boiling batch until reach $90^{\circ} \mathrm{C}$ for $5 \mathrm{~min}$, then immediately cooled in an ice bath to $42^{\circ} \mathrm{C}$, inoculated with $0.4 \mathrm{~mL} / 100 \mathrm{~mL}$ of ST culture, and with $0.4 \mathrm{~mL} 100 \mathrm{~mL}^{-1}$ of LB, LA or BL culture. All inoculated milks were incubated for fermentation at $42^{\circ} \mathrm{C}$ in a water bath until $\mathrm{pH} 4.50$ was reached, which corresponded to the final fermentation time (time to reach $\mathrm{pH} 4.5=\mathrm{t}_{\mathrm{pH} 4.5}$ ).

Each fermentation, performed in two replicates, was monitored by using the Cinac system (Spinnler and Corrieu 1989), which allows a continuous recording of $\mathrm{pH}$ and computes acidification rates during fermentation. Chemical changes during fermentation were followed by measuring kinetics parameters: $V_{\max }$ (maximum acidification rate that measures the decrease of $\mathrm{pH}$ units per minute and the values are expressed as $\left.\mathrm{mUpH} \min ^{-1}\right), t_{\mathrm{Vmax}}$ (time to achieve the maximum acidification rate, in $\mathrm{h}$ ), $\mathrm{t}_{\mathrm{pH} 5}$ (time to achieve $\mathrm{pH} 5.0$, in $\mathrm{h}$ ) and $\mathrm{t}_{\mathrm{pH} 4.5}$ (time necessary to reach $\mathrm{pH} 4.5$, in $\mathrm{h}$ ). When fermented milk reaches $\mathrm{pH} 4.5$, it was stirred by manually stirring with a stainless steel perforated disk by up and down movements for almost $1 \mathrm{~min}$. The product was set into a $50 \mathrm{~mL}$ cups which were sealed using a thermal machine Selopar (BrasHolanda, Brazil) and, rapidly cooled in an ice bath. The fermented milks were then stored at $4{ }^{\circ} \mathrm{C}$.

\section{Chemical determinations}

The protein content of the heat treated milk was determined by ultrasonic milk analyzer Ekomilk (Eon Trading, Bullgary). The total solids content was determined by drying under vacuum at $70^{\circ} \mathrm{C}$, until constant weight (Case et al., 1992).

The acidity of the fermented milks was determined by $\mathrm{pH}$ measurement using a $\mathrm{pH}$ meter model Q-400M1 (Quimis, Brazil). This allows studying the post acidification of the samples. Analyses were performed in duplicate after 1 (d1) and weekly until 28 days of storage of the products at $4^{\circ} \mathrm{C}$.

\section{Textural properties}

\section{Rheological behavior}

The rheological behavior parameters were determined at $10^{\circ} \mathrm{C}$ using a rotational rheometer Physica MCR300, (Physica, Stutgart, Germany). The rheometer was equipped with a plate and plate geometry $(50 \mathrm{~mm}$ diameter and $1.0 \mathrm{~mm}$ gap). Flow tests were performed with shear rate varying from 0.01 to $20 \mathrm{1} / \mathrm{s}$. Amplitude sweep tests were performed to ascertain the linear viscoelastic region (LVE) of the fermented milks, with shear stress between 0,01 and 5 $\mathrm{Pa}$ at frequency of $1 \mathrm{~Hz}$. To examine the long term behavior in the state of rest a frequency sweep test at a constant shear stress of $0.5 \mathrm{~Pa}$ and frequency ranging from 0.02 to $10 \mathrm{~Hz}$ was carried out. The rheological parameters of storage modulus G', loss modulus G' and complex viscosity $\eta^{*}$ were compared. All rheological testes were performed in duplicate, and only data from $\mathrm{d} 1$ are presented, because samples shown the same behavior during storage, with no differences between yogurt and probiotic fermented milks. 
Firmness

Penetration tests were performed with a TA-XT2 Texture Analyser (Stable Micro Systems, Godalming, England) in the samples in plastic cups, at $4-6^{\circ} \mathrm{C}$. The probe used was an acrylic cylinder (diameter: $2.5 \mathrm{~cm}$ ), moving at a pre-test speed of $5 \mathrm{~mm} / \mathrm{s}$ and test speed of $10 \mathrm{~mm} / \mathrm{s}$ trough a distance of $10 \mathrm{~mm}$ in the sample. The penetration force in $\mathrm{N}$ was recorded as the firmness. Texture analysis were performed with 4 samples each date, after 1 (d1) and weekly until 28 days of storage of the products at $4^{\circ} \mathrm{C}$.

\section{Microbiological analysis}

Enumeration of bacteria was carried out for milk immediately after inoculation, to obtain the initial counts for each bacteria, after the fermented milk products were stored at $4^{\circ} \mathrm{C}$ for $24 \mathrm{~h}$ (day 1), and weekly until 28 days. Each sample was prepared according to the methods described by the International Dairy Federation (IDF, 1996, 1997, 2003). ST was enumerated on M17 Agar (Oxoid, England) at $37^{\circ} \mathrm{C}$ aerobically for $48 \mathrm{~h}$. LB and LA were enumerated on MRS Agar (Oxoid, England) acidified to $\mathrm{pH} 5.4$ with acetic acid, after anaerobic incubation at $37^{\circ} \mathrm{C}$ for $72 \mathrm{~h}$. BL was enumerated on MRS Agar (Oxoid, England) after anaerobic incubation at $37^{\circ} \mathrm{C}$ for $72 \mathrm{~h}$. The selectivity of the growth conditions was confirmed by microscope appearance of the cells from single colonies. Microbiological analyses were performed in duplicate during storage of the products at $4{ }^{\circ} \mathrm{C}$.

\section{RESULTS AND DISCUSSION}

\section{Chemical changes during fermentation}

Heat treated milk used for fermentation presented total solids and protein contents of $12.6 \mathrm{~g}$

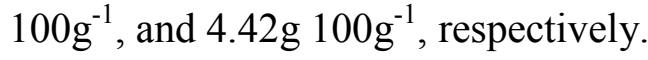

The acidification kinetics of milk fermented by yogurt and probiotic bacteria was obtained by measuring continuously the changes in $\mathrm{pH}$ by means of glass electrodes according the method of Spinnler and Corrieu (1989). The $\mathrm{pH}$ was automatically recorded at two min intervals and the acidification kinetics was calculated from the $\mathrm{pH}$-time curves (Table 1). Maximum acidification rates, $\mathrm{V}_{\max }$, were $22.1 \times 10^{-3} \mathrm{upH} \mathrm{min}^{-1}, 19.2 \times 10^{-3} \mathrm{upH} \mathrm{min}^{-1}$ and $20.0 \times 10^{-3} \mathrm{upH} \mathrm{min}^{-1}$ for STLB, STLA and STBL, respectively. Time to achieve the maximum acidification rate, $t_{V \max }$, increased for the probiotic cultures: $3.1 \mathrm{~h}$ for STLB and 3.2h for STLA and 3.3h for STBL. Time to achieve $\mathrm{pH} 5.0, \mathrm{t}_{\mathrm{pH} 5.0}$, also increased from yogurt to probiotic bacteria. Fermentation time $\left(t_{\mathrm{pH} 4.5}\right)$ obtained using the yogurt starter culture (STLB) was $5.5 \mathrm{~h}$, which was lower than those obtained with probiotic bacteria: $8.4 \mathrm{~h}$ using co-culture STLA and 8.0h using STBL (Table 1). These results are similar to those reported by many researchers who confirmed that probiotic bacteria have a lower acidification performance in milk when compared with a yogurt starter culture (Klaver et al., 1993; Marshall and Tamime, 1997; Saxelin et al., 1999; Oliveira et al., 2001; Sodini et al., 2002; Damin, 2003). 
Table 1: Chemical changes during fermentation of milk by Streptococcus thermophilus (ST) in co-culuture with Lactobacillus delbrueckii ssp. bulgaricus (LB), Lactobacillus acidophilus (LA), and B. lactis (BL).

\begin{tabular}{lcccc}
\hline Culture & $\mathbf{V}_{\mathbf{m}}$ & $\mathbf{t}_{\mathbf{V} \mathbf{m a x}}$ & $\mathbf{t}_{\mathbf{p H 5 . 0}}$ & $\mathbf{t}_{\mathbf{p H 4 . 5}}$ \\
& $\left(\mathrm{mUpH} \mathrm{min}^{-1}\right)$ & $(\mathrm{h})$ & $(\mathrm{h})$ & $(\mathrm{h})$ \\
\hline STLB & 22.1 & $3.1^{\mathrm{a}}$ & $3.7^{\mathrm{a}}$ & $5.5^{\mathrm{a}}$ \\
STLA & 19.2 & $3.2^{\mathrm{ab}}$ & $4.3^{\mathrm{b}}$ & $8.4^{\mathrm{b}}$ \\
STBL & 20.0 & $3.3^{\mathrm{c}}$ & $4.2^{\mathrm{b}}$ & $8.0^{\mathrm{b}}$ \\
\hline
\end{tabular}

Means values of three determinations. Values with different letters in the same row are significantly different $(P<0.05)$.

$\mathrm{V}_{\mathrm{m}}$ : maximum acidification rate; $\mathrm{t}_{\mathrm{Vmax}}$ : time to achieve the maximum acidification rate; $\mathrm{t}_{\mathrm{pH} 5.0}$ : time to achieve $\mathrm{pH} 5.0 ; \mathrm{t}_{\mathrm{pH} 4.5}$ : time necessary to reach $\mathrm{pH} 4.5$.

Whatever the conditions of production, yogurts and fermented milks shown a $\mathrm{pH}$ fall during refrigerated storage, called post-acidification. According to Figure 1, the main decrease in $\mathrm{pH}$ occurred between $\mathrm{d} 1$ and $\mathrm{d} 7$. This result can be caused by the lactose consumption and lactic acid production. The milk fermented by STLB, STLA and STBL shown $\mathrm{pH}$ decrease of $0.17,0.12$ and 0.25 , respectively, similar characteristics of commercial products were reported by Rybka and Fleet (1997), Moreira et al. (1999), and Nogueira et al. (1998).

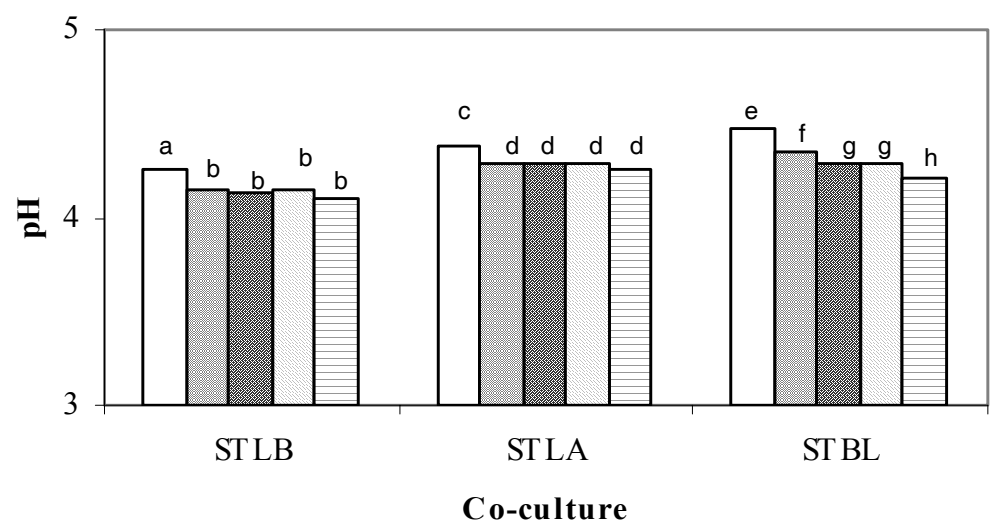

$\square \mathrm{d} 1 \square \mathrm{d} 7 \mathrm{O} \mathrm{d} 14 \square \mathrm{d} 21 \square \mathrm{d} 28$ 
Fig. 1: Effect of time of cold storage on $\mathrm{pH}$ of fermented milks by Streptococcus thermophilus (ST) in co-culture with Lactobacillus delbrueckii ssp. bulgaricus (LB), Lactobacillus acidophilus (LA), and B. lactis (BL). Co-culture dates with different letters are significantly different $(P<0.05)$.

\section{Textural properties}

Flow curves between 0.01-20 1/s are reported in Figure 2 for the milks fermented by the cocultures. The curves have similar behaviors of the stress profiles with discontinuities in shear rate around $1.7 .10^{-2}$ and in $1.5 .10^{\circ}$. The viscosity curve is correlated with the structural state of the material and falls with increasing shear rate. At 0.01 of shear rate, the viscosity were 9.4.10 $20^{2}, 1.2 .10^{3}, 1.0 .10^{3}$ for STLB, STLA and STBL, respectively and for shear rate of 1 the viscosity were $1.3 .10^{1}, 1.9 .10^{1}, 1.5 .10^{1}$ for the same products. This flow behavior is a shearthinning or pseudoplastic, as reported on the literature (De Lorenzi et al., 1995).

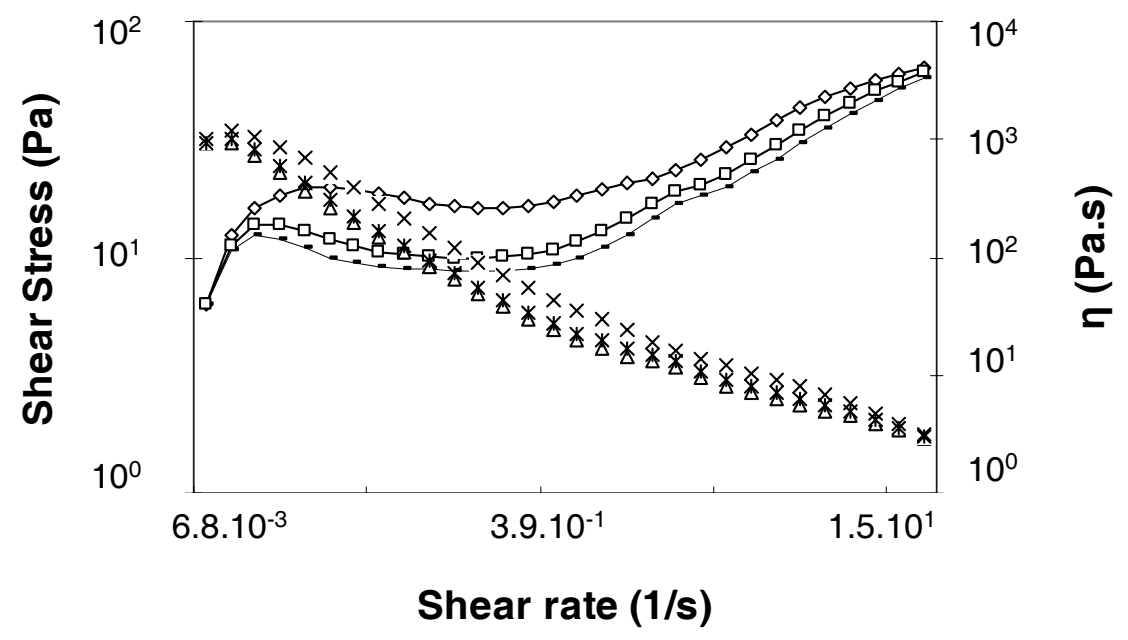

Fig. 2: Shear stress (-) STLB, $(\diamond)$ STLA, $(\square)$ STBL and viscosity $(\eta)$ curves $(\Delta)$ STLB, $(\times)$ STLA and (*) STBL for milk fermented by yoghurt and probiotic cultures. $S$. thermophilus (ST), L. bulgaricus (LB), L. acidophilus (LA) and B. lactis (BL).

The amplitude sweep curves (Figure 3) characterize the consistency at rest related to the stability during storage. Curves for all fermented milks showed the same linear viscoelastic deformation range, with the plateau limit at shear stress $=1.8 .10^{0} \mathrm{~Pa}$. G' values were higher than $G$ " for all samples, indicating elastic characteristic. 


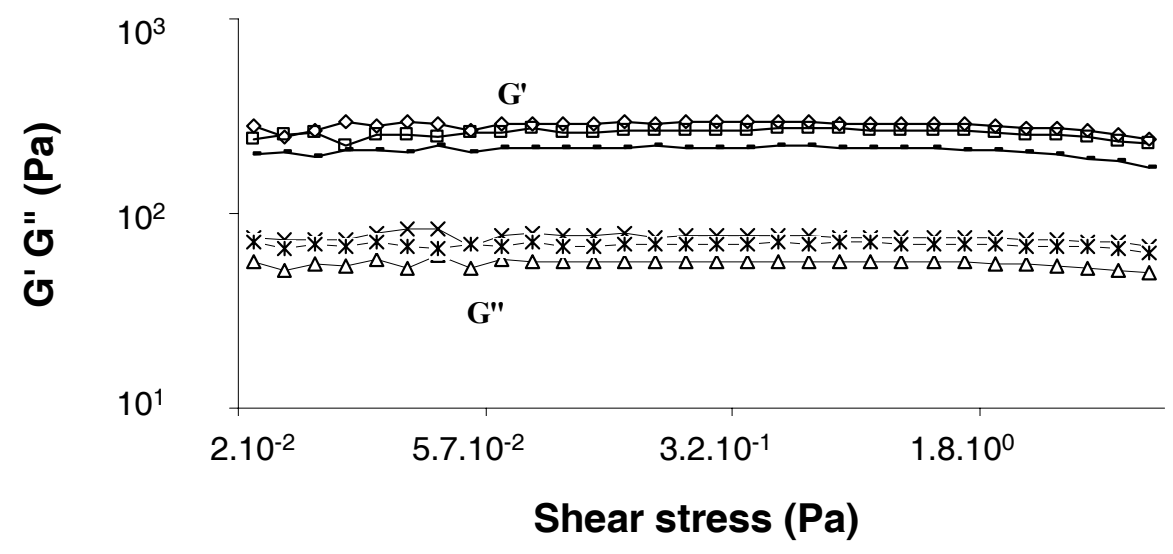

Fig. 3: Amplitude sweep curves for fermented milks show storage modulus G' $(-)$ STLB, $(\diamond)$ STLA, ( $\square)$ STBL and loss modulus G" for $(\Delta)$ STLB, $(\times)$ STLA and $(*)$ STBL. $S$. thermophilus (ST), L. bulgaricus (LB), L. acidophilus (LA) and B. lactis (BL).

From the frequency sweep test, reported in Figure 4, it could be seen storage modulus G' and complex viscosity $\eta^{*}$. Results for milk fermented by STLA and STBL are slightly higher than for STLB. The frequency dependence of $G^{\prime}$ are similar, all augmented with increasing frequency. $\eta^{*}$ at $0.02 \mathrm{~Hz}$ were $1.1 \times 10^{3}, 1.6 \times 10^{3}$ and $1.4 \times 10^{3}$, and at $10 \mathrm{~Hz}$ were $5.3 \times 10^{0}$, $7.9 \times 10^{\circ}$ and $7.1 \times 10^{\circ}$, for STLB, STLA and STBL, respectively.

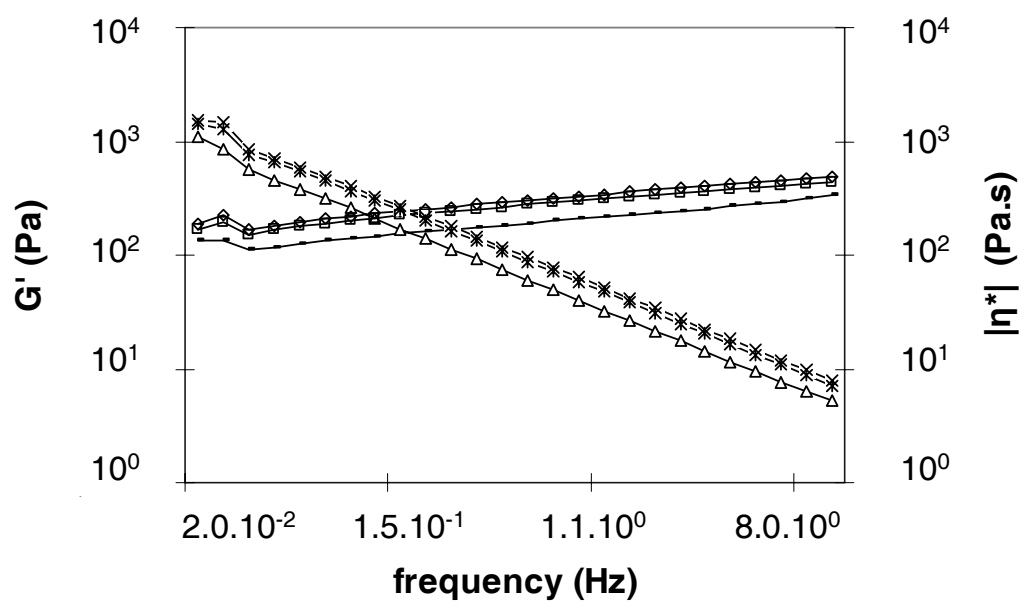

Fig.5: Frequency sweep curves for milk fermented by $(-)$ STLB, $(\diamond)$ STLA, ( $\square$ ) STBL; and complex viscosity curves for $(\Delta)$ STLB, $(\times)$ STLA and (*) STBL. S. thermophilus (ST), $L$. bulgaricus (LB), L. acidophilus (LA) and B. lactis (BL). 
The cultures have no significant effect on rheologycal parameters resulting that the rheologycal parameters of milk fermented by probiotic bacteria are similar of that from milk fermented by yogurt bacteria.

Firmness at d1 was significant higher for milk fermented by STLA $(475 \mathrm{mN})$, the strain that showed the longest fermentation time, followed by STBL $(412 \mathrm{mN})$ and STLB $(407 \mathrm{mN})$. The same firmness behavior related to fermentation time was observed in previous works (Kristo et al. 2003; Damin, 2003). Similar firmness values of fermented milks were reported by Oliveira et al. (2001). Changes in firmness during the storage period are presented in Figure 6. The firmness increased $35 \%, 25 \%$ and $53 \%$ from d 1 to d28 for STLB, STLA and STBL, respectively. For long period storage an improvement of texture in stirred yogurt was noticed and this could be due the formation of bonds between the protein particles (Sodini et al. 2004).

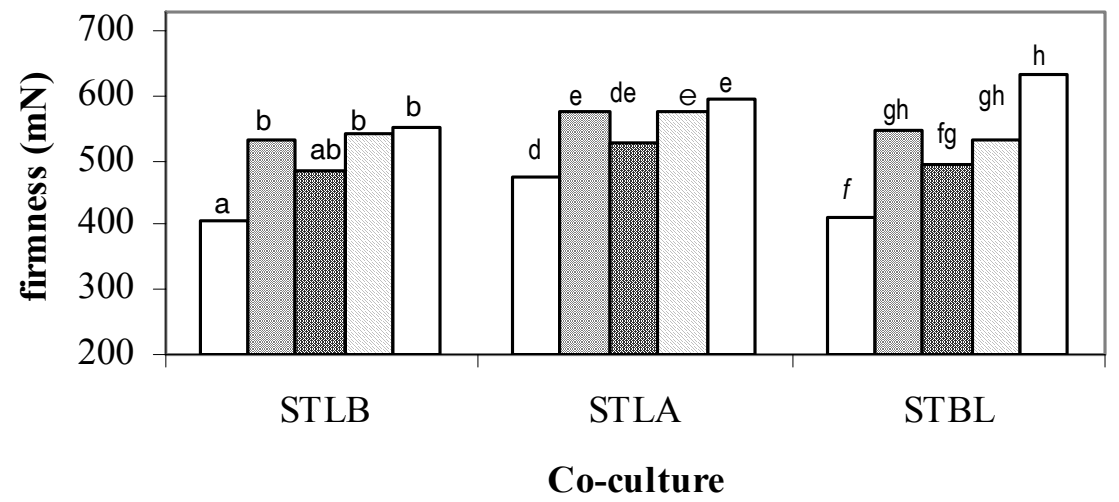

$\square \mathrm{d} 1 \mathrm{~d} \mathrm{~d} 7 \mathrm{~d} 14 \square \mathrm{d} 21 \square \mathrm{d} 28$

Fig. 6: Effect of time of cold storage on firmness of fermented milks by Streptococcus thermophilus (ST), Lactobacillus delbrueckii ssp. bulgaricus (LB), Lactobacillus acidophilus (LA) and B. lactis (BL). Co-culture dates with different letters are significantly different $(P<0.05)$.

\section{Viability}

Yogurt and probiotic fermented milk are beneficial to human health because of the type of bacteria and dose of viable cells they contain. Although quantitative standards differ from $10^{6}$ to $10^{7} \mathrm{cfu} / \mathrm{g}$ viable cells as minimum requirements, it is recommended that yogurt or fermented milk should contain at least 1 million viable cells per gram at the time of consumption. Consequently it is important to test the probiotic bacteria for the growth and viability during cold storage. The average initial microbial count for each of the activated culture was $\sim 10^{7} \mathrm{cfu} \mathrm{mL}^{-1}$. Initial counts for the inoculated milks before fermentation were similar for ST, LA and BL, but not for LB (Table 2). In spite of a carefully preparation of inocula, the spray-dried culture LB340 doesn't fit the same cell number as the others. The fermented milk was cooled in an ice bath after reach $\mathrm{pH} 4.5$ and we considered the counts at $\mathrm{d} 1$ as the final count at the fermentation end. The average population of each strain is shown in Table 2. These numbers indicate that the probiotic strains grow appreciably during fermentation ( 2 log cycles), although yogurt bacteria counts resulted in a higher growth (3 
$\log$ cycles), especially due $S$. thermophilus counts. The number o ST dominated over the other strains and remained stable during all storage period. B. lactis and L. bulgaricus attain the final storage period stable. L. acidophilus, however, decreased before 14 days of storage and at $\mathrm{d} 28$ doesn't fit the minimum requirements to achieve beneficial properties to health.

Gueimonde et al. (2004) reported that only five of ten analyzed commercial probiotic fermented milks fulfilled the requirement of containing high viable cells $/ \mathrm{mL}$. In general, the ST counts were higher than the lactobacilli, and remained stable during the storage period at levels ranging between $10^{-7}$ and $10^{-9} \mathrm{cfu} / \mathrm{mL}$ (Dave and Shah, 1997; Gilliland and Speck, 1997; Rybka and Fleet, 1997; Moreira et al., 1999).

Table 2: Population of each culture in inoculated milk initially and after fermentation at $\mathrm{d} 1$, $\mathrm{d} 7, \mathrm{~d} 21$ and $\mathrm{d} 28$ of storage at $4^{\circ} \mathrm{C}$.

\section{Culture}

$\left(\log \mathrm{cfu} \mathrm{mL} L^{-1}\right)$

\begin{tabular}{ccccc}
\hline Time & S. thermophilus & L. bulgaricus & L. acidophilus & B. lactis \\
\hline Before fermentation & 6.39 & 5.36 & 6.40 & 6.46 \\
d1 & 9.28 & $8.20^{\mathrm{gh}}$ & $8.08^{\mathrm{d}}$ & $8.98^{\mathrm{k}}$ \\
d7 & 9.36 & $8.22^{\mathrm{hi}}$ & $8.08^{\mathrm{d}}$ & $8.14^{\mathrm{ef}}$ \\
d14 & 9.31 & $8.37^{\mathrm{j}}$ & $7.59^{\mathrm{c}}$ & $8.16^{\mathrm{efg}}$ \\
d21 & 9.43 & $8.26^{\mathrm{i}}$ & $6.95^{\mathrm{b}}$ & $8.11^{\mathrm{de}}$ \\
d28 & 9.33 & $8.19^{\mathrm{fgh}}$ & $5.18^{\mathrm{a}}$ & $8.07^{\mathrm{d}}$ \\
\hline
\end{tabular}

Each value is a mean of duplicate $\log \mathrm{cfu} \mathrm{mL}^{-1}$ at each date. The dark zone indicates data in which statistics were applied. Values with different letters are significantly different $(P<0.05)$.

\section{CONCLUSIONS}

This study has shown that the behavior of probiotic cultures differ from yogurt cultures in fermentation time, although they grow 2 log cycles during this time. On the other hand the probiotic fermented milk shown similar textural properties to fermented milk by yogurt cultures. Lactobacillus acidophilus decreased during cold storage until 28 days to a level that doesn't fulfill the minimum viable counts to reach health beneficial effects. Bifidobacterium lactis and yogurt bacteria remained stable.

\section{ACKNOWLEDGEMENTS}

The authors wish to thank FAPESP (The State of São Paulo Research Foundation), CAPES and $\mathrm{CNPq}$ for financial support, and DANISCO for furnishing the cultures 


\section{REFERENCES}

Case, R.A., Bradley Jr., R.L., Williams, R.R. 1992. Chemical and physical methods. p.327404. In: American Public Health Association. Standard methods for the examination of dairy products.

Damin, M.R. 2003. Master dissertation. Faculty of Pharmaceutical Sciences, São Paulo University. 116p.

Dave, R.I., Shah, N.P. 1997. Int. Dairy J., 7:31.

Dave, R.I., Shah, N.P. 1998. J Dairy Sci., v.81:2804.

De Lorenzi, L., Priel, S., Torriano, G. 1995. Int. Dairy J., 5:661.

Gardiner, G.E., Ross, R.P., Kelly, P.M., Stanton, C. 2002. Microbiology of therapeutic milks. p.431-478. In: Dairy Microbiology Handbook, ed. R.K.Robinson, John Wiley \& Sons Inc.

Gilliland, S.E., Speck, M.L. 1977. J. Dairy Sci., 60:1395.

Goldin, B.R. 1998. Br. J. Nutr., 80:S203.

Gueimonde, M., Delgado, S., Mayo, B., Ruas-Madiedo, P., Margolles, A., Reyes-Gavilán, C.G. 2004. Food Res. Int., 37:839.

Holzapfel, W.H., Haberer, P., Snel, J., Schillinger, U., Huis In’t Veld, J.H.J. 1998 Int. J. Food Microbiol., 41:85.

IDF 1996. Preparation of Samples and Dilutions for Microbiological Examination, Standard No. 122C, International Dairy Federation, Brussels, Belgium.

IDF 1997. Dairy Starter Cultures of Lactic Acid Bacteria (LAB) - Standard of Identity, Standard No. 149A, International Dairy Federation, Brussels, Belgium.

IDF 2003. Yoghurt / Enumeration of Characteristic Microorganisms - Colony Count Technique at $37^{\circ} \mathrm{C}$, Standard No. 117, International Dairy Federation, Brussels, Belgium.

Kailasapathy, K., Rybka, S. 1997. Aust. J. Dairy Technol., 52:28.

Klaver, F.A.M., Kingman, F., Weerkamp, A.H. 1993. Neth. Milk Dairy J., 47:151.

Kristo, E., Biliaderis, C.G., Tzanetakis, N. 2003. Int. Dairy J., 13:517.

Kurmann, J.A., Rasic, J.L. 1991. The health potential of products containing bifidobacteria. p. 117-158. In: Therapeutic Properties of Fermented Milks, Robinson RK ed., Elsevier Applied Science.

Lourens-Hattingh, A., Viljoen, B.C. 2001. Int. Dairy J., 11:1. 
Lucey, J.A., Munro, P.A., Singh, H. 1998. J. Texture Stud., 29:413.

Marshall, V.M., Tamime, Y.A. 1997. Int. J. Dairy Technol., 50 (1):35.

Mattila-Sandholm, T., Mättö, J., Saarela, M. 1999. Int. Dairy J., 9:25.

Moreira, S.R., Schwan, R.F., Carvalho, E.P., Ferreira, C. 1999. Ciênc. Tecnol. Aliment., 19:147.

Nogueira, C., Albano, H., Teixeira, P. 1998. J. Ind. Microbiol. Biotechnol., 21:19.

Oliveira, M.N., Sodini, I., Remeuf, F., Corrieu, G. 2001. Int. Dairy J., 11:935.

Oliveira, M.N., Sivieri, K., Alegro, J.H.A., Saad, S.M.I. 2002. Rev. Bras. Ciênc. Farm., 38(1):1.

Ouwehand, A.C., Salvadori, B.B., Fondén, R., Mogensen, G., Salminen, S., Sellars, R. 2003. IDF Bulletin, 380, p.4.

Rybka, S., Fleet, G.H. 1997. Food Aust., 49:471.

Rybka, S., Kailasapathy, K. 1995. Aust. J. Dairy Technol., 50:51.

Salminen, S., Ouwehand, A.C., Isolauri, E. 1998. Int. Dairy J., 8:563.

Saxelin, M., Grenov, B., Svensson, U., Fondén, R., Reniero, R., Mattila-Sandholm, T. 1999. Trends Food Sci. Technol., 10:387.

Shah, N.P, Lankaputhra, E.V., Britz, M.L., Kyle, W.S.A. 1995. Int. Dairy J., 5:515.

Shah, N.P. 2000. J. Dairy Sci., 83:894.

Sodini, I., Remeuf, F., Haddad, S., Corrieu, G. 2004. Critical Reviews in Food Science and Nutrition, 44:113.

Sodini, I., Lucas, A., Oliveira, M.N., Remeuf, F., Corrieu, G. 2002. J. Dairy Sci., 85:2479.

Spinnler, H.E., Corrieu, G. 1989. J. Dairy Res., London, 56:755.

Tamime, A.Y., Marshall, V.M.E., Robinson, R.K. 1995. J. Dairy Res., 62:151. 